\title{
BIODEGRADATION OF AZO DYE REMAZOL BLACK 5 BY MONO CULTURE BACTERIA WITH TEMPE INDUSTRIAL WASTEWATER AS CO-SUBSTRATE
}

\author{
Puti Sri Komala $^{1^{*}}$, Yommi Dewilda ${ }^{1}$, Zilvia Wulandari ${ }^{1}$ \\ ${ }^{1}$ Department of Environmental Engineering, Faculty of Engineering, Andalas University, \\ Padang 25163, Indonesia
}

(Received: February 2013 / Revised: May 2013 / Accepted: June 2013)

\begin{abstract}
Azo dye is one of the synthetic organic dye groups most widely used in the textile industry. The release of this component into the environment can be harmful to the living organisms and the ecosystems. Therefore, it is necessary to treat wastewater containing dye before it is discharged into the water bodies. The decolorization using mono- or mixed culture has been developed for decades because of its environmental friendly and evidence of completely mineralization. Sixteen species of pure culture bacteria derived from aerobic-anoxic membrane bioreactor were used for biodegradation of azo dye Remazol Black 5 using tempe industrial wastewater as cosubstrate. The optimum co-substrate concentration for biomass growth under shaking condition was $40 \% \mathrm{v} / \mathrm{v}$ or $2,560-2,720 \mathrm{mg} \mathrm{COD} / \mathrm{L}$, while dye decolorization under this condition was not significant. The azo dye biodegradation in anaerobic condition was best shown by the Isolate A1A, Exiguobacterium sp. A2, and Bacillus sp. A4 with removal efficiency of $43.82 \%, 29.94 \%$ and $35.91 \%$ respectively. The highest color degrading bacteria were also the highest organics removing bacteria. It was confirmed that dye docolorization process required a carbon source addition.
\end{abstract}

Keywords: Azo dye Remazol Black 5; Biodegradation; Mono culture; Tempe industrial wastewater

\section{INTRODUCTION}

Approximately 60-70\% of more than 10.000 dyes used in textile industries are azo dyes (Méndez-Paz et al., 2005). Azo dye is characterized with double bond nitrogen compound in its chemical structure. The exposure of high dye concentration in textile industrial wastewater to humans may cause detrimental effects to health, such as skin- and eye irritation and may even cause cancer (Mathur et al., 2005). Biodegradation of azo dyes may take place in anaerobic or aerobic conditions, or in the combination of anaerobic-aerobic processes (Van der Zee, 2002). An external carbon source should be added during biodegradation to support microorganisms growth. The co-substrate can be simple organic compounds such as glucose, acetate, ethanol, starch or complex organic compounds such as yeast extract, peptone, or a combination of complex organic sources and carbohydrates (Chen et al., 2003; Khehra et al., 2005 ). Yeast extract has been proven to be one of the most effective supplements to get high color removal efficiency. However, the cost of yeast extract is very expensive, especially if it is used in a continuous experiment and is applied in an industrial scale. It is required to find cheaper substitute materials whose composition is not much different from yeast extract. Wastewater generated from the tempe manufacture can be an alternative as a substitute material. 
Tempe is one of the Indonesian traditional food sources derived from fermented soybeans and its wastewater still contains high content of organic compounds, proteins, vitamins and trace minerals (Sudarjanto, 1998), that can still be recovered as external carbon sources in the biological process. Wisjnuprapto et al. (1999) and Wahyuni et al. (2002) have used tempe wastewater as co-substrates for azo dye biodegradation that demonstrated high color removal.

Furthermore, biodegradation of azo dye Remazol Black 5 had been carried out in a continuous experiment using an aerobic-anoxic membrane bioreactor (Komala, 2011). The bioreactor consisted of anoxic-, contact- and stabilization tanks connected to an external ultrafiltration membrane located between the contact- and stabilization tanks with tempe wastewater as the co-substrate. The color removal efficiency obtained was in the range of 76-87\%. The dominant microorganisms were isolated from each tank, and 16 pure culture species were obtained. In this research the ability of those bacteria in biodegradation of azo dye Remazol Black 5 using tempe wastewater as a co-substrate was evaluated through observation on their potential in color and organics removal. The optimum co-substrate concentration for microorganisms growth was determined and it further was used for azo dye biodegradation experiments. From this study it can be known which microorganisms played a role in decolorization and organics removal derived from tempe wastewater.

\section{EXPERIMENTAL}

The 16 species of pure microorganisms were isolated from anoxic, contact, stabilization and membrane reactors from previous research (Komala, 2011).The bacteria isolated from the mixed liquor of anoxic reactor were Isolate A1A, Exiguobacterium sp. A1C, Exiguobacterium sp. A2, Isolate A3, Bacillus sp. A4, from the suspended solids of contact reactor were Raoultella sp. K1, Comamonas aquatica K2, Bacillus amyloliquefaciens K4A, Comamonas aquatiac K4B, from the mixed liquor of stabilization reactor were Shewanella putrefaciens S1, Bacillus substilis S3, Exiguobacterium sp. S4, Isolate S5 and bacteria that came from the attached sludge inside the membrane were Shewanella putrefaciens M1, Enterobacter asburiae M2, Comamonas aquatica M3A. Bacillus, Raoultella, and Comamonas bacteria. These bacteria belong to the aerobic bacteria. The bacteria known as Shewanella, Exiguobacterium, and Enterobacter are included in the facultative anaerobic bacteria. Each bacterium was grown in a NA medium (Nutrient Agar) and enriched in a broth medium without agar using $250 \mathrm{~mL}$ erlenmeyer flasks that were covered by sterile cotton and shaken at $80 \mathrm{rpm}$.

The azo dye Remazol Black 5 (RB 5) was used in this study purchased from Dystar agency. The initial concentration was fixed about $120 \mathrm{mg} / \mathrm{L}$. The color was measured with Unico 1100 RS spectrophotometer based on the maximum absorbance at a $600 \mathrm{~nm}$ wavelength in the visible range. As co-substrates we used tempe industrial wastewater derived from residual water boiling soybeans. Some parameters in tempe industrial wastewater were measured for chemical characteristics such as: $\mathrm{pH}$, metal compounds, BOD, COD, nitrogen compounds, sulfate, phosphate, and chloride. The next process was the optimization of tempe wastewater concentration as co-substrate by using three species bacteria namely Isolate A1A, Raoutella sp. $\mathrm{K} 1$ and Shewanella putrafaciens S1. A $250 \mathrm{~mL}$ erlenmeyer flask was used as reactor and was filled with each monoculture microorganism with a $120 \mathrm{mg} / \mathrm{l}$ concentration of azo dye Remazol Black 5, and tempe wastewater. The tempe wastewater was varied in concentration between $10 \%$ and $50 \% \mathrm{v} / \mathrm{v}$. The reactor was covered by sterile cotton and shaken at $80 \mathrm{rpm}$. The shaking condition was performed to see the effects of aeration to microorganisms growth (Chen et al., 2003; Kalme et al., 2007; An et al., 2002). The optimum concentration of co-substrate was determined through the highest biomass growth rate and the lowest concentrations of COD effluents. The samples were taken at the initial time and every four hours for 24 hrs to measure biomass growth as VSS, COD- and color concentrations. All parameters were measured 
according to APHA (Eaton et al., 1995), i.e. VSS by gravimetric method, COD by closed reflux titrimetric method and color by specthrophotometric method.

The optimum co-substrate concentration obtained from the previous study was applied for azo dye biodegradation experiments using 16 pure bacteria species, each in $250 \mathrm{ml}$ erlenmeyer flask. The flask was covered by a siphoned trap containing water for a gas trap and to keep an anaerobic condition in place. The reactor content was similar as the previous experiment except for the co-substrate was used as the optimum concentration. Subsequently, the reactor was flushed with nitrogen gas to expel oxygen and then was shaken at $80 \mathrm{rpm}$ on the rotary shaker. Samples were taken at the initial time and at every 4 hours for 36 hours using a syringe needle for color, COD, BOD (winkler titration method) and VSS measurement.

\section{RESULTS AND DISCUSSION}

\subsection{Characteristic of Tempe Industrial Wastewater}

Characteristics of industrial wastewater compared to yeast extract and the other study are shown in Table 1. The organics content of the tempe wastewater was 5,880 mg COD/L and 1,865 mg $\mathrm{BOD} / \mathrm{L}$, it was lower than that from the previous research (Komala, 2011), namely 53,670 mg $\mathrm{COD} / \mathrm{L}$ and $1.865 \mathrm{mg} \mathrm{BOD} / \mathrm{L}$, nevertheless, this was higher compared to $4 \mathrm{~g} / \mathrm{L}$ yeast extract, i.e. 3,167 mg COD/L (Komala, 2011).

Table 1 Characteristics of tempe industrial wastewater

\begin{tabular}{lccc}
\hline Parameters & Yeast Extract $4 \mathrm{~g} / \mathrm{L}^{*}$ & Tempe Wastewater* & Tempe Wastewater in this study \\
\hline $\mathrm{pH}$ & 6.64 & 4,18 & 4.79 \\
$\mathrm{COD}(\mathrm{mg} / \mathrm{l})$ & 3,167 & 53,670 & 5,880 \\
$\mathrm{BOD}(\mathrm{mg} / \mathrm{l})$ & $\mathrm{Nm}^{\#}$ & 16,110 & 1,865 \\
$\mathrm{NO}_{3}(\mathrm{mg} / \mathrm{l})$ & 1.08 & 11.9 & 219.69 \\
$\mathrm{NO}_{2}(\mathrm{mg} / \mathrm{l})$ & 14.21 & 227.9 & 2.15 \\
$\mathrm{NH}_{4}(\mathrm{mg} / \mathrm{l})$ & $\mathrm{Nm}$ & $\mathrm{Nm}$ & 453 \\
$\mathrm{TKN}^{-}(\mathrm{mg} / \mathrm{l})$ & $\mathrm{Nm}$ & 746 & 690 \\
$\mathrm{Cl}^{-}(\mathrm{mg} / \mathrm{l})$ & 15.42 & 69.6 & 74.3 \\
$\mathrm{PO}_{4}{ }^{3-}(\mathrm{mg} / \mathrm{l})$ & 65.06 & 382 & 587 \\
$\mathrm{SO}_{4}{ }^{2-}(\mathrm{mg} / \mathrm{l})$ & 23,89 & 269.3 & 115.78 \\
$\mathrm{Al}(\mathrm{mg} / \mathrm{l})$ & 0.04 & 1.8 & 7.93 \\
$\mathrm{Ca}(\mathrm{mg} / \mathrm{l})$ & 1.95 & 125.5 & 9.28 \\
$\mathrm{Fe}(\mathrm{mg} / \mathrm{l})$ & 0.09 & 17.2 & 10.47 \\
$\mathrm{~K}(\mathrm{mg} / \mathrm{l})$ & 159.5 & 2,236 & 12.76 \\
$\mathrm{Mg}(\mathrm{mg} / \mathrm{l})$ & 1.16 & 363.7 & 8.81 \\
$\mathrm{Na}(\mathrm{mg} / \mathrm{l})$ & 7.69 & 87.2 & 10.96 \\
\hline
\end{tabular}

* Komala (2011); ${ }^{*}$ Nm, not measured

Meanwhile, the total nitrogen and the phosphate content were not much different compared to the other tempe industrial wastewater, i.e. $690 \mathrm{mg} / \mathrm{L}$ as the total Kjedahl Nitrogen and 587 $\mathrm{mg} / \mathrm{L}$ as the phosphate. In terms of biological treatment, a ratio of BOD:N:P of 100:5:1 for carbon source and the nutrients are generally used for a sufficient nutrient requirement for biomass growth (Dewanti, 2010). This value is larger than the ratio of BOD:N:P found in this study i.e. 19:7:6, however, tempe wastewater has been proven previously as an effective external carbon source for azo dye biodegradation with a relatively high-performance color removal (Wisjnuprapto et al., 1999; Wahyuni et al., 2002; Komala, 2011). The high organic content and nutrients in tempe wastewater can meet the microorganism growth requirement in biological treatment. Based on these reasons tempe wastewater can be the appropriate choice as a co-substrate for azo dye biodegradation. The concentration difference of the parameters found 
in the tempe industrial effluent might be due to the different quality of soybean types, processes, and certain chemicals added during the tempe manufacturing process.

\subsection{Optimization of Tempe Wastewater Concentration as a Co-substrate}

As the co-substrate, tempe wastewater addition in the range of $10 \% \mathrm{v} / \mathrm{v}$ to $20 \% \mathrm{v} / \mathrm{v}$ in medium did not fulfill the requirement for Isolate A1A, Raoutella sp. K1 and Shewanella putrafaciens $\mathrm{S} 1$ growth. Increasing the tempe wastewater concentration up to $40 \% \mathrm{v} / \mathrm{v}$ in the medium for these three bacteria resulted in the increase of biomass- and organics removal simultaneously. However, at the higher substrate concentration addition $(50 \% \mathrm{v} / \mathrm{v})$ in the medium caused a decrease of biomass and organics removal in conformity. The optimum co-substrate concentration of the three bacteria was obtained at $40 \%$ tempe wastewater $\mathrm{v} / \mathrm{v}$ or $2,560 \mathrm{mg}$ $\mathrm{COD} / \mathrm{L}$ (Figure 1). The Isolate A1A shown indicated that the lowest COD concentration in effluent i.e. $800 \mathrm{mg} / \mathrm{L}$ and the highest biomass increased i.e. from 1,640 mg VSS/L to 3,578 mg VSS/L after 36 hrs (Figure 2).

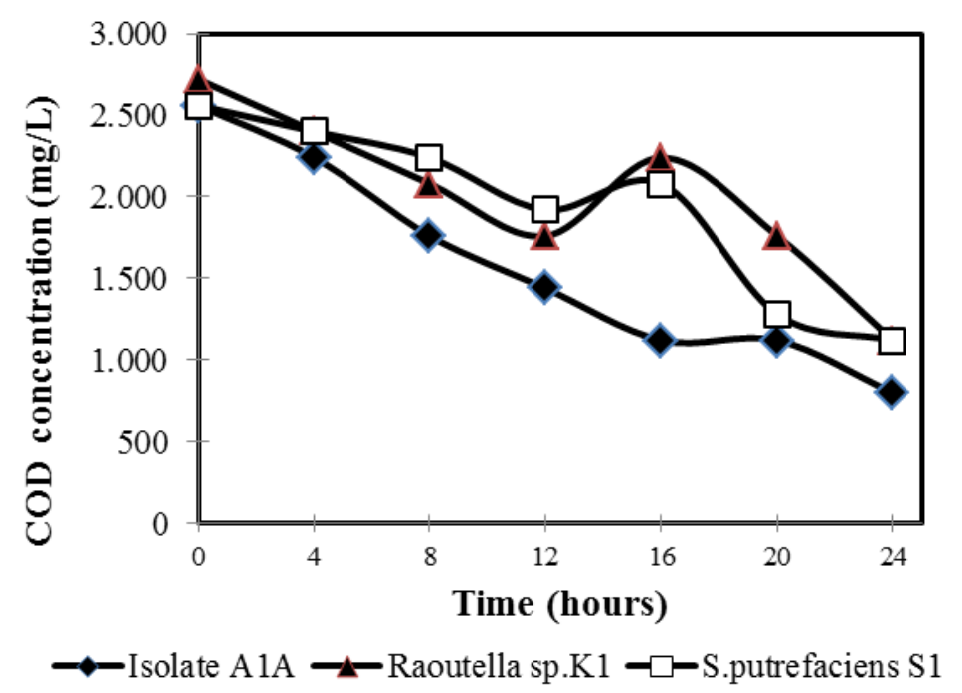

Figure 1 Comparison of COD removal efficiencies between monoculture bacteria in optimum cosubstrate concentration $40 \% \mathrm{v} / \mathrm{v}$ or 2,560 $\mathrm{mg}$ COD/L and azo dye RB $5120 \mathrm{mg} / \mathrm{L}$ at shaking conditions

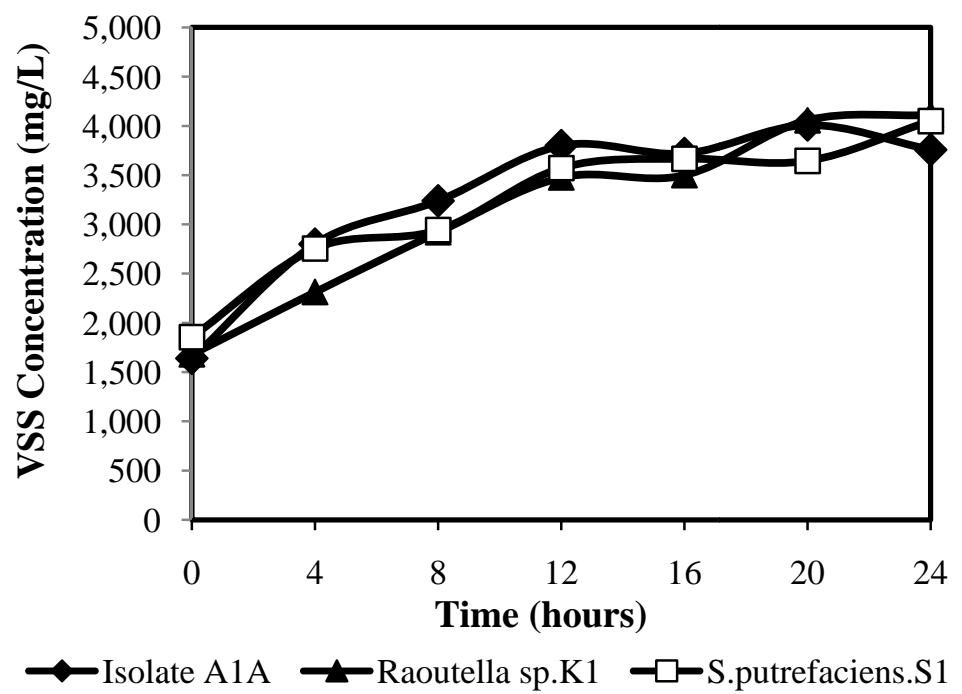

Figure 2 Biomass growth of monoculture bacteria in optimum co-substrate concentration $40 \% \mathrm{v} / \mathrm{v}$ or 2,560 mg COD/L and azo dye RB $5120 \mathrm{mg} / \mathrm{L}$ at shaking conditon 
The aerobic condition performed in these experiments contributed to insignificant decolorization i.e. from $120 \mathrm{mg} / \mathrm{L}$ at initially to a $112 \mathrm{mg} / \mathrm{L}$ azo dye concentration (Figure 3).

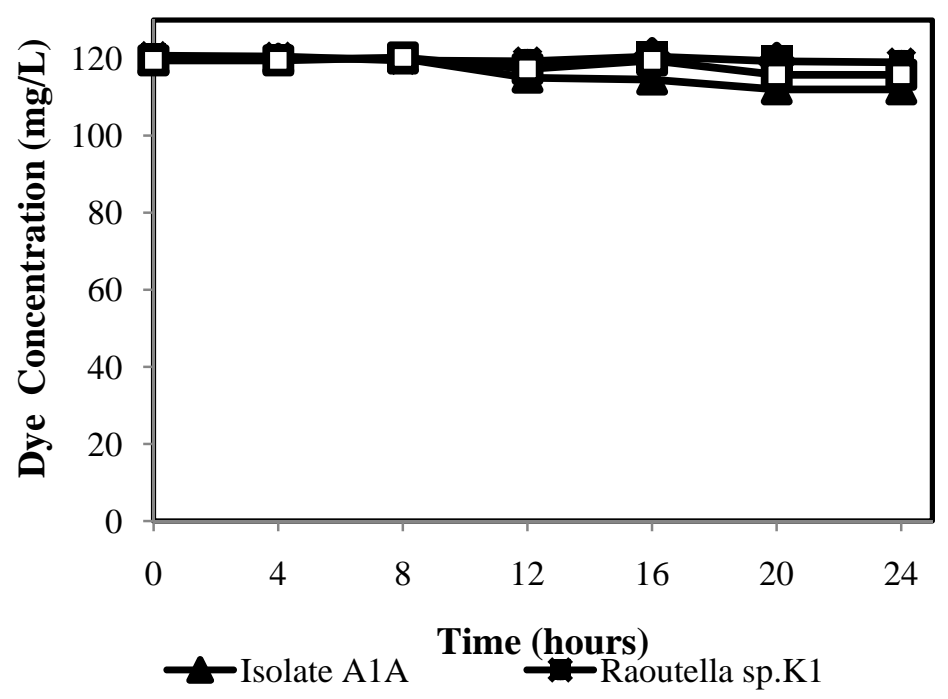

Figure 3 Decolorization in optimum co-substrate concentration $40 \% \mathrm{v} / \mathrm{v}$ or 2,560 $\mathrm{mg}$ COD/L and azo dye RB $5120 \mathrm{mg} / \mathrm{L}$ at shaking conditon

There was an optimum co-substrate concentration added in the medium containing the dye to get both the highest COD removal efficiency and microorganisms growth under shaking conditions or the presence of oxygen. Meanwhile, the decolorization occurring under an aerobic condition almost did not happen. Under this condition, the oxygen would be preferred as an electron acceptor rather than the dye. In an aerobic condition microorganisms used the carbon source such as an electron donor whilst oxygen is used as an electron acceptor. Therefore, azo dye biodegradation is ineffective under an aerobic condition. Azo dye biodegradation under an anaerobic condition required an external carbon source. Tempe industrial wastewater in addition to a carbon source also provides high organic nitrogen sources and trace elements which are required for microorganisms growth and metabolisms. These elements contributed to produce coenzyme NADH which acts as an electron donor for azo bond cleavage under an anaerobic condition (Saratale et al., 2009).

\subsection{Biodegradation of azo dyes Remazol Black 5 with Monoculture Bacteria}

The removal efficiency of azo dye Remazol Black 5, COD, and BOD by 16 species bacteria under anaerobic condition is shown in Table 2.

Each bacteria have a different ability for azo dye biodegradation. Under an anaerobic condition all bacteria grew only to less than $600 \mathrm{mg}$ VSS/L. This is much lower compared to the shaking condition, i.e. 3,578 mg VSS/L (Figure 4). In this condition the presence of dye has inhibited microorganisms growth. Despite the limited number of microorganisms, their ability to degrade organics material and azo dye were high (Figure 5 and Figure 6). Specifically Isolate A1a with a biomass concentration of less than $400 \mathrm{mg} / \mathrm{L}$ reached the highest COD- and color removal efficiency. In general, the bacteria derived from the anoxic tank have a higher ability to decolorize dye than the other bacteria, such as Isolate A1A that reduced the color by $43.82 \%$, Exiguobacterium sp. A2 29.94\% and Bacillus sp. A4 35.91\% respectively. While in the others, the bacteria only reduced dye for smaller than $10 \%$ removal efficiency. The highest dye decolorizing bacteria were also the highest organics degrading bacteria. This confirms that the 
color removal takes place in an anaerobic condition required a carbon source, while biomass growth was carried out better in an aerobic condition.

Table 2 Removal efficiency of color, COD and BOD in biodegradation process at initial concentration of azo dye RB $5120 \mathrm{mg} / \mathrm{L}$ and 2,560 mg COD/L and $806 \mathrm{mg}$ BOD/L)

\begin{tabular}{lrrr}
\hline \multirow{2}{*}{\multicolumn{1}{c}{ Bacteria }} & \multicolumn{3}{c}{ Efficiency (\%) } \\
\cline { 2 - 4 } & Color & COD & BOD \\
\hline Isolate A1A & 43.82 & 68.75 & 53.31 \\
Exiguobacterium sp.A2 & 29.94 & 52.94 & 38.10 \\
Isolate A3 & 2.09 & 17.65 & 15.79 \\
Bacillus sp.A4 & 35.91 & 56.25 & 42.35 \\
Exiguobacterium sp.A1C & 3.34 & 12.50 & 12.11 \\
Raoutella sp.K1 & 1.04 & 11.76 & 13.22 \\
Bacillus amyloliquefaciens. K4A & 6.08 & 29.41 & 19.46 \\
Commonas aquatica.K4B & 8.32 & 35.29 & 30.92 \\
Shewanella putrefaciens S1 & 3.97 & 18.75 & 14.90 \\
Bacillus substilis sp.S3 & 2.73 & 12.50 & 15.09 \\
Exiguobacterium sp.S4 & 0.42 & 5.88 & 3.98 \\
Isolate S5 (+) & 1.04 & 11.76 & 10.52 \\
Shewanella putrefaciens M1 & 2.71 & 12.50 & 13.72 \\
Enterobacter asburiae M2 & 3.13 & 18.75 & 16.44 \\
Commonas aquatica M3A & 1.25 & 11.76 & 11.42 \\
Commonas aquatica K2 (+) & 2.31 & 12.50 & 10.68 \\
Control 1 (Dye) & 0.00 & 0.00 & 0.00 \\
Control 2 (Dye + Co-substrate) & 0.21 & 0.00 & 0.00 \\
\hline
\end{tabular}

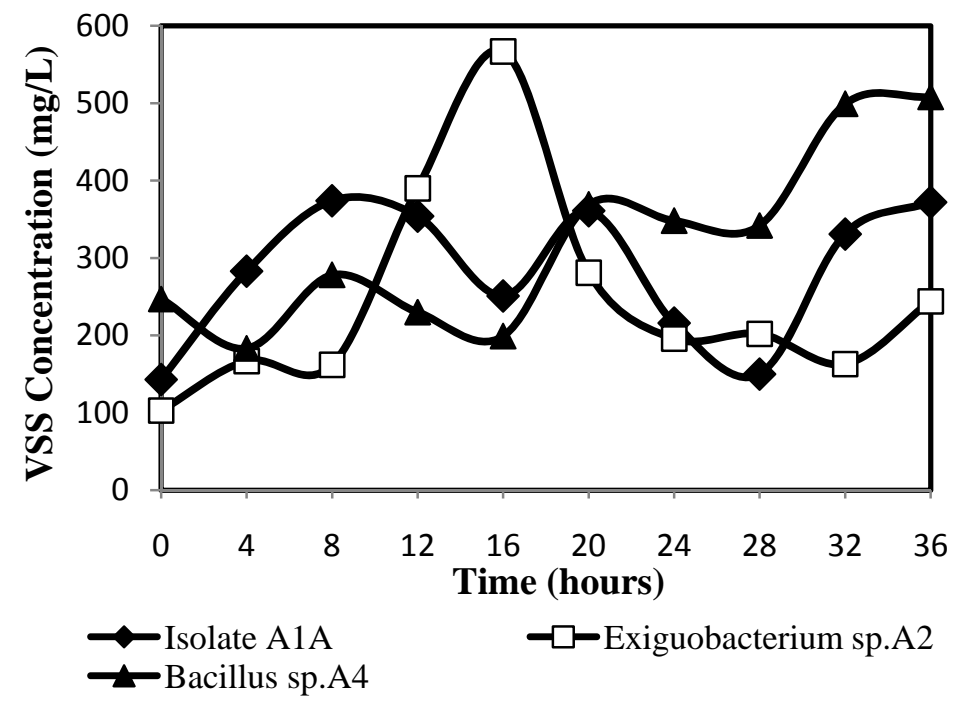

Figure 4 Biomass growth under anaerobic conditions at an initial concentration of azo dye RB 5120 $\mathrm{mg} / \mathrm{L}$ and 2,560 $\mathrm{mg} \mathrm{COD} / \mathrm{L}$ ) 


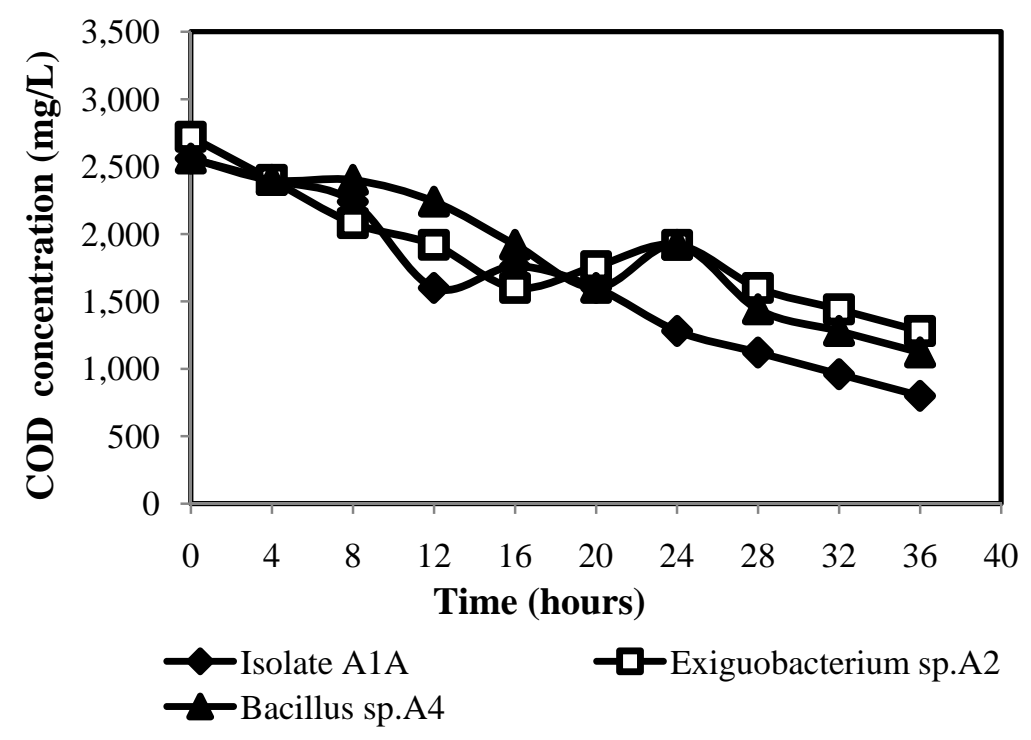

Figure 5 COD removal efficiencies under anaerobic conditions at an initial concentration of azo dye RB

$5120 \mathrm{mg} / \mathrm{L}$ and 2,560 mg COD/L)

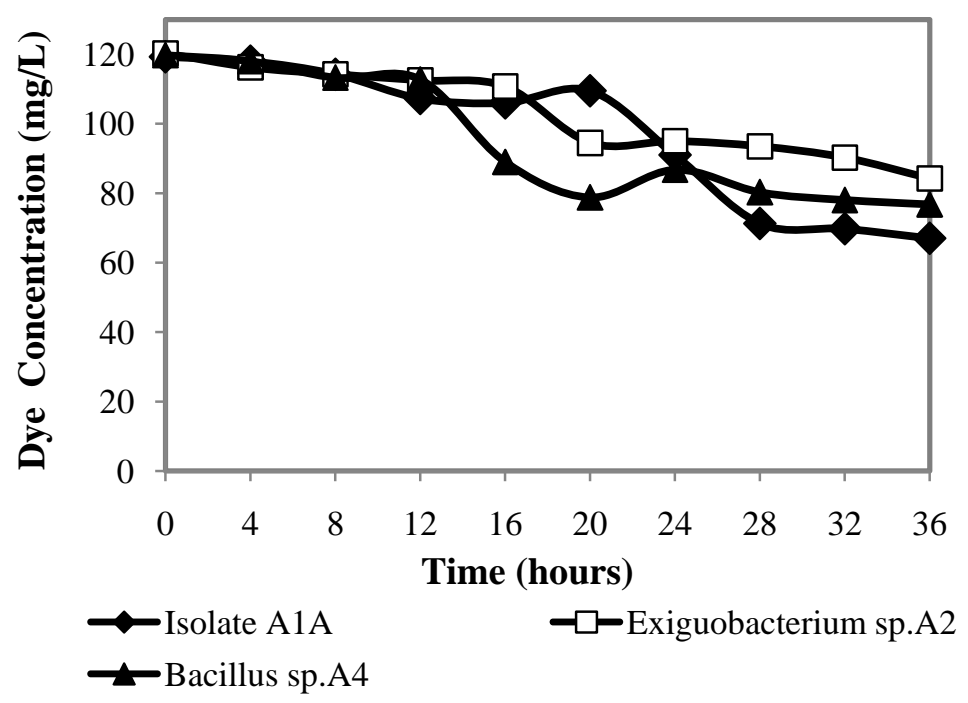

Figure 6 Decolorization under anaerobic conditions at an initial concentration of azo dye RB 5120 $\mathrm{mg} / \mathrm{L}$ and 2,560 $\mathrm{mg} \mathrm{COD} / \mathrm{L}$ )

Compared to the Komala's study (2011) of azo dye RB5 biodegradation using an aerobicanoxic membrane bioreactor by consortium bacteria was able to decolorize RB5 87\% and reduce COD 88\%, meanwhile using monoculture bacteria derived from aerobic-anoxic membrane bioreactor's tanks showed lower decolorization, i.e. $43.82 \%$ and $68.75 \%$ for COD removal. However, this experiment confirmed that both in consortia and individual form, the bacteria originating from an anoxic tank still showed the same ability both in terms of decolorization and COD removal. At the end of experiment the BOD/COD ratio of Isolate A1A was 0.471 higher than that of the initial i.e. 0.371 or 1.3 times of the initial value. The increase of BOD/COD ratio indicated that the wastewater become more biodegradable due to the simple aromatic amines formation as color metabolite products. 


\section{CONCLUSION}

The color removal of $120 \mathrm{mg} / \mathrm{L}$ concentration of azo dye Remazol Black 5 by mono culture bacteria was optimum with $40 \% \mathrm{v} / \mathrm{v}$ tempe industrial wastewater or $2,540 \mathrm{mg} \mathrm{COD} / \mathrm{L}$ as cosubstrates. The bacteria Isolate A1A, Bacillus sp. A4, and Exiguobacterium sp. A2 from an anoxic tank showed the highest removal of azo dye among the sixteen bacteria with removal efficiencies of $43.82 \%, 29.94 \%$ and $35.91 \%$, respectively. The best organics removal was carried out by Isolate A1A with removal efficiency of 68.75\% (COD) and 53.31\% (BOD). The ratio of $\mathrm{BOD} / \mathrm{COD}$ in the effluent increased to 0.471 or 1.3 times of the initial ratio due to metabolite products formation that resulted from azo dye cleavage and created more biodegradable wastewater for further treatment.

\section{ACKNOWLEDGEMENT}

This study was supported by the Andalas University's Grant Year 2012 No. 001/PL/SPK/PNP/FT-Unand/2012 and Directorate General of Higher Education, Ministry of National Education 2013, No. 17/UN.16/PL-HB/2013.

\section{REFERENCES}

An, S.Y., Min, S.K., Cha, I.H., Choi Y.L., Cho, Y.S., Kim, C.H., Lee, Y.C., 2002. Decolorization of Triphenylmethane and azo dyes by Citrobacter sp., Biotechnology Letters, Volume 24(12), pp. 1037-1040.

Chen, K.C., Huang, W.T., Wu, J.Y., Houng, J.Y., 1999. Microbial Decolorization of azo dyes by Proteus mirabilis, Journal of Industrial Microbiology and Biotechnology, Volume 23(1), pp. 686-690.

Dewanti, B.S.D., 2010. Industrial Wastewater Treatment by Aerobic and Anoxic Membrane Bioreactor (MBR), Department of Chemical Engineering, Faculty of Industrial Engneering ITS, Surabaya, Indonesia.

Eaton, A.D., Clesceri, L.S., Greenberg, A.E. (Eds.), 1995. American Public Health Association: Standard Methods for the Examination of Water and Wastewater. $19^{\text {th }}$ ed., Washington D.C.

Kalme, S.D., Parshetti, G.K., Jadhav, S.U., Govindwar, S.P., 2007. Biodegradation of Benzidine based dye Direct Blue-6 by Pseudomonas desmolyticum NCIM 2112, Bioresource Technology, Volume 98(7), pp. 1405-1410.

Khehra, M.S., Saini, H.S., Sharma, D.K., Chadha, B.S., and Chimni, S.S., 2005. Decolorization of Various azo dyes by Bacterial Consortia, Dyes and Pigments, Volume 67, pp. 55-61.

Komala, P.S., 2011. Removal of azo dye Remazol Black 5 using Aerobic-anoxic Membrane Bioreactor and Its Effects on Microorganisms Population Dynamics, Doctoral Disertation, Study Programme of Environmental Engineering ITB, Bandung, Indonesia.

Mathur, N. Bhatnagar, P., Bakre, P., 2005. Assessing Mutagenicity of Textile dyes from Pali (Rajasthan) using Ames Bioassay, Applied Ecology and Environmental Research, Volume 4(1), pp. 111-118.

Méndez-Paz, D., Omil, F., Lema, J.M., 2005. Anaerobic Treatment of azo dye Acid Orange 7 under Batch Conditions. Enzyme Microbiol Technol, Volume 36(2-3), pp. 264-272.

Saratale, R. G., Saratale, G. D., Kalyani, D. C., Chang ,J. S., Govindwar, S.P., 2009. Enhanced Decolorization and Biodegradation of Textile azo dye Scarlet $\mathrm{R}$ by using Developed Microbial Consortium-GR. Bioresource Technology, Volume 100(9), pp. 2493-2500.

Sudarjanto, G., 1998. CIRO dye 16 Removal and Its Kinetics using a Combination of Contact Stabilization Process and Activated Carbon Adsorption, Master Thesis, Study Programme of Environmental Engineering ITB, Bandung, Indonesia.

Van der Zee, F.P., 2002. Anaerobic azo dye Reduction, Doctoral Thesis, Wageningen University, Netherlands. 
Wahyuni, S., Mubiarti, E., Yunita, R., 2002. Gas Measurement for Treating Wastewater Containing CIRB 5 dye with Concentration of $60 \mathrm{mg} / \mathrm{L}$ in the Sequencing Batch Biofilm Reactor (SBBR). Informatek, Volume 5(4), pp. 153-160.

Wisjnuprapto, Kardena, E., Artha, W., 1999. Removal of azo dye CIRO-16 in the Modification of Contact Stabilization Process using Tempe Industrial Wastewater. Journal Biosains, Volume 4(1), pp. 26-30. 